\title{
SOSIOLOGI ISLAM : REFLEKSI ATAS KEBERAGAMAAN UMAT ISLAM DI INDONESIA ANTARA DOGMA, AJARAN, DAN REALITAS
}

\section{Sampean}

Mahasiswa Pascasarjana Program Master Sosiologi Pedesaan, Institut Perta-nian Bogor

Sampean_pian@apps.ipb.ac.id

\begin{abstract}
Abstrak
Sosiologi Islam adalah disiplin keilmuan yang membekukan kajiannya di ranah kelompok masyarakat Islam. Sosiologi Islam berupaya memotret kelompok masyarakat Islam yang memiliki sistem budaya kemasyarakatan yang terbangun atas sistem nilai, keyakinan, historis, dan moralitas sendiri. Sosiologi Islam merefleksikan sikap keberagamaan umat Islam di Indonesia yang menunjukkan pola hubungan tiga fase historis dan simbolis dapat disimpulkan menjadi empat hal yakni ketegangan perumusan dasar negara, ketegangan ideologis, kediktatoran negara, dominasi mayoritas. Pola hubungan yang terbentuk menunjukkan bias dari objektivitas dogma agama Islam.
\end{abstract}

Kata Kunci : Sosiologi Islam, Keberagamaan, Kuntowijoyo, ISP

\section{PENDAHULUAN}

Persoalan keberagamaan umat Islam di Indonesia dapat ditinjau dalam perspektif teologis maupun sosiologis. Pada aspek teologis, Islam dipahami sebagai ajaran paripurna, pedoman hidup, dan laku baik. Sedangkan, perspektif sosiologi memfokuskan pada realitas sosial yang menunjukkan bentuk - bentuk penyimpangan nilai dan tata laku yang tidak sesuai dengan ajaran Islam. Pada konteks ini, disiplin keilmuan sosiologi hadir sebagai pengurai kenyataan atau menghadirkan kenyataan 
sosial sebagai pembelajaran yang ditinjau dari aspek kelembagaan, struktural, kontrol, dan diskursus yang berlangsung dalam kelompok masyarakat. Sebab, fenomena keberagamaan- bukan hanya sebagai persoalan individu tetapi juga persoalan kelompok atau bukan hanya persoalan teologis, pengetahuan, dan kesadaran. Tapi juga, persoalan struktural dimana penguasa atau negara terlibat dalam mengontrol keberagamaan.

Dalam konteks Indonesia, persoalan keberagamaan berbanding lurus dengan keberagaman masyarakat Indonesia. Dimensi keberagaman digambarkan dari aras lokal ke aras nasional. Per- soalan keberagamaan dimulai dari dimensi konflik teologis, radikalisme, dan terorisme, konflik Antaragama, antarsuku, dan konflik politik agama. Relung - relung konflik tersebut mencuat ke publik sebagai isu pemecah kebangsaan Negara Kesatuan Republik Indonesia [NKRI]. Dalam pandangan Kusumadewi (2012) bahwa ketidakharmonisan yang berlangsung berdasarkan agama menyebabkan praktik eksklusi sosial melalui proses pengabaian, pengasingan, dan pencabutan hak atas orang atau kelompok atas agamanya. Ketidakharmonisan atas agama menunjukkan bahaya laten atas disintegrasi sebuah bangsa. Oleh karena itu, agama harus diposisikan sebagai faktor penyokong keberlangsungan masyarakat atau sebuah bangsa.

Distribusi populasi enam agama di Indonesia di dominasi agama Islam sebesar 87,18 atau sekitar 207.176.162 juta jiwa. Setelah itu diikuti agama kristen sebesar 6,96\% atau 16.528.513 juta jiwa. Sedangkan, agama Kristen Katolik sebesar $2,91 \%$ atau 6.907 .873 juta jiwa, agama Hindu sebesar 1,69 $\%$ atau 4.012.116 juta jiwa, agama Budha sebesar 0,72\% atau 1.703.254 juta jiwa, Konghucu sebesar 0,05\% atau 117.091 juta jiwa dan agama lainlain $0,41 \%$ atau 1.196 .317 Juta jiwa. Data ini didasarkan dari pola distribusi populasi agama yang dirilis data Badan Pusat Statistik [BPS] Indonesia Tahun 2010 menunjukkan bahwa fenomena keberagamaan didominasi oleh keberadaan agama Islam.

Data BPS 2010 juga menunjukkan Keberadaan Islam di posisi minoritas hanya empat dari tiga puluh tiga provinsi di antaranya Nusa Tenggara Timur [NTT] hanya sebesar 9,05\% selebihnya agama katolik sebesar 54,14\%, dan kristen $34,74 \%$. Ketiga ini sebagai agama dominan di NTT. Selanjutnya, 
Sulawesi Utara, di dominasi agama Kristen 63,60 dan Islam $30,90 \%$, Papua didominasi agama Kristen 65,48\% dan Islam 15,89\%, dan di Papua Barat agama Kristen sebesar 53,77 \% dan Islam 38,40\%

Dari distribusi populasi keberagamaan dapat disimpulkan enam hal yakni pertama, dibalik pluralitas agama di Indonesia, Islam adalah agama mayoritas penduduk Indonesia Kedua, determinasi pola relasi antaragama didominasi dengan penganut agama Islam; Ketiga potensi kediktatoran mayoritas Islam atas klaim ke- benaran; Keempat, dominasi struktural; Kelima, ketimpangan atas nama agama mayoritas; keenam, dominasi kriminalitas atas agama mayoritas. Fenomena ini menjadi titik krusial bagi keberlangsungan kebangsaan Indonesia. Masalah ini tidak bisa dijelaskan secara teologis bahwa persoalan agama hanya persoalan keyakinan antara penganutnya dan pencapaian hidup sebagai realitas politis. Tapi, fenomena tersebut adalah fenomena sosiologis.

Gejala sosiologis yang berlangsung ini dapat ditinjau dalam pendekatan Sosiologi, khususnya Sosiologi Islam. Penyebutan Sosiologi Islam dalam dunia akademik belum cukup lazim dan kontroversial. Penggabungan kata Sosiologi dan Islam adalah dua hal yang sangat berjauhan di mana Sosiologi sebagai disiplin keilmuan yang bertugas melihat gejala dan fenomena sosial dan Islam sendiri adalah konsepsi teologis dan fenomena sosial. Jika, Islam sebagai fenomena sosial Maka, Islam tidak bisa dilepaskan sebagai fakta sosiologis yang di dalamnya mengandung kontrol dan perekat sosial dan Islam realitas kemasyarakatan. Maka, tugas utama dari sosiologi Islam adalah menyingkap pola relasi keberagamaan umat Islam di Indonesia yang berkaitan erat dengan hubungan antara agama Islam dengan non Islam dan Islam dengan Islam, Islam dengan kearifan lokal, dan Islam sebagai realitas fenomena teologis. Maka, menurut Berger (1985) tugas seorang sosiolog harus melakukan pembongkaran [debungkin] atau mengurai tirai yang menghalangi kenyataan yang sesungguhnya dan mengutamakan netralitas dalam memotret sebuah persoalan.

\section{SOSIOLOGI ISLAM}

Sosiologi Islam sebagai disiplin keilmuan dalam menganalisis konteks masyarakat di Indonesia belum berakar kuat. Pengenalan 
kajian sosial berbasiskan Islam dilakukan oleh Kuntowijoyo mengenai Ilmu Sosial Profetik [ISP]7. Kajian ISP adalah upaya mengilmukan Islam dalam melihat fenomena sosial, bukan proses Islamisasi ilmu (Jurdi 2010). Pengilmuan Islam adalah upaya membangun disiplin keilmuan yang utuh dalam mengkaji fenomena kemasyarakatan dari Islam itu sendiri. Pengilmuan Islam adalah tawaran dari Kuntowijoyo untuk kebaikan umat manusia dengan nilai - nilai keislaman dan menjawab kebutuhan Islam itu sendiri

Pengaruh ISP dari Kuntowijoyo dalam perkembangan kelahiran sosiologi Islam cukup kuat di Indonesia. Misalnya, lahirnya karya Syarifuddin Jurdi tahun 2014, Sosiologi Islam dan Masyarakat Modern dan Sosiosophologi: Sosiologi Islam berbasiskan hikma dari Abidin, Zainal, Agus Ahmad

7 Pengenalan Kajian Ilmu sosial profetik sebagai bentuk paradigma keilmuan dalam aspek ontologi, epistemologi, dan aksiologi diperkenalkan dalam karya Kuntowijoyo. 2007. Islam sebagai Ilmu: Epistemologi, Metodologi, dan Etika yang didalamnya mengandung nilai nilai humanisasi dimaknai penegakan kebajikan, liberasi dimaknai pembebasan dan atau emansipasi, dan transendensi yakni penegakan nilai nilai keagamaan sebagai dasar pengetahuan.
Safei, and Maman Abdul Djaliel di tahun 20038. Dari kedua karya menjadi rujukan utama kajian sosiologi Islam. Meskipun, pengaruh secara pemikiran ISP tidak cukup. ISP sebagai kerangka pemikiran dan teori belum menjadi kajian analisis sosial dalam kedua buku ini. Mereka masih berdiri di kaki masing - masing. Tulisan lain yang mengarahkan ISP ke dalam bentuk satu disiplin keilmuan dan rumusan pemikiran adalah Muttaqin (2015) dan dan Abidin (2016).9 Semantara, di artikel ini,

8 Dalam karya Syarifuddin Jurdi meletakkan dasar pemikiran teoritis dan analitis sosiologi islam dalam melihat konteks masyarakat. Pemikiran Syarifuddin Jurdi sangat dipengaruhi dengan pemikiran ilmu khaldun sedangkan sosiophologi Abidin, Zainal, Agus Ahmad Safei, and Maman Abdul Djaliel membangun paradigmanya berdasarkan hikma keislaman.

9 Di tulisan Husnul Muttaqin. 2015. Menuju Sosiologi Profetik hanya menarasikan kembali gagasan Kuntowijoyo dengan memaksakan pendisiplin sosiologi profetik. Muh. Zaenal Abidin.2016. Paradigma Islam: dalam Pembangunan Ilmu Integralistik membaca pemikiran Kuntowijoyo adalah upaya menggali kembali pemikiran Kuntowijoyo secara kritis dengan merumuskan kembali sistem gagasan integralisasi keilmuan. Di mana Kuntowijoyo memandan antar barat dan timur suatu yang oposisi biner. Keilmuan barat yang imperialis/ superior dan Timur yang imperior. 
sosiologi Islam menjadi alat analisis [analysis tool] dalam melihat fenomena keberagamaan Islam di Indonesia. Tinjauan sosiologi Islam dalam artikel tidak melepaskan analisis ilmuwan barat dan ISP Kuntowijoyo dalam meletakkan sosiologi Islam sebagai alat analisis membedah keberagamaan Islam di Indonesia.10

Dalam kerangka pemikiran ISP, Kuntowijoyo berupaya mendirikan suatu disiplin keilmuan yang tidak meniadakan wahyu sebagai sumber dan dasar pengetahuan. Dalam konteks keberagamaan wahyu dan ajaran, tata laku, tindakan, kontrol, dan kohesivitas adalah bagian integral dari realitas sosial. Gagasan kewahyuan dalam pemikiran Kuntowijoyo disebut strukturalisme transendental. Strukturalisme transendental menjadi kunci utama penegakan pilar - pilar keilmuan dalam pengimplementasian humanisasi, liberasi, dan transendensi. Dimensi lain dari

10 Dalam dimensi kajian sosiologi yang di dominasi ilmuwan barat tidak bisa dilepaskan dari pengembangan kajian keilmuan. Pemisahan antara ilmuwan barat dan timur sudah tidak lagi relevan dalam pengembangan ilmu sosiologi. Sebab, setiap pemikiran atau teori menemukan konteksnya masingmasing dalam masyarakat. Maka, tokoh - tokoh barat dalam analisis sosiologi islam di Artikel ini. gagasan Kuntowijoyo (2006) dalam memandang kehidupan masyarakat bahwa masyarakat adalah semesta simbolis. Semesta simbolik ini yang mengonstruksi kategori - kategori sosial yang terbentuk di masyarakat. Sedangkan, secara metodologi ISP menggunakan integralisasi dan objektivikasi. Asumsi dasar peletakan ISP sebagai bentuk pengilmuan Islam adalah bukan Islam sebagai agama tapi Islam sebagai kesadaran kolektif yang memiliki sistem pengetahuan dan bentuk kemasyarakatan. Perbedaan Islam sebagai ilmu dan agama sebagai berikut :

Tabel 1.0 Perbedaan Islam

sebagai ilmu dan agama

\begin{tabular}{|c|c|c|}
\hline Keterangan & $\begin{array}{c}\text { Islam } \\
\text { sebagai } \\
\text { Agama }\end{array}$ & $\begin{array}{c}\text { Islam } \\
\text { Sebagai Ilmu }\end{array}$ \\
\hline $\begin{array}{c}\text { Interpretasi } \\
\text { Teks }\end{array}$ & Subjektivitas & Objektivitas \\
\hline $\begin{array}{c}\text { Kesadaran } \\
\text { Aktor }\end{array}$ & $\begin{array}{c}\text { Kesadaran } \\
\text { Subjektif }\end{array}$ & $\begin{array}{c}\text { Kesadaran } \\
\text { kolektivitas }\end{array}$ \\
\hline $\begin{array}{c}\text { Kesadaran } \\
\text { Teks }\end{array}$ & Normatif & Teoritis \\
\hline $\begin{array}{c}\text { Analisa } \\
\text { Teks }\end{array}$ & Ahistoris & Historis \\
\hline Kewahyuan & $\begin{array}{c}\text { general dan } \\
\text { mistik }\end{array}$ & $\begin{array}{c}\text { Spesifik dan } \\
\text { demistifikasi }\end{array}$ \\
\hline Doktrin & Dogma & $\begin{array}{c}\text { Ajaran dan } \\
\text { empirik }\end{array}$ \\
\hline Sumber : Kuntowiloyo
\end{tabular}

Sumber : Kuntowijoyo (2006) (2007) 
Islam dalam konteks keyakinan dan Islam sebagai ilmu memiliki perbedaan yang cukup signifikan dan memiliki relevansinya di masyarakat. Islam sebagai dasar keyakinan bertumpu pada kesadaran subjektivitas baik dalam memahami teks maupun dalam menjalankan syariatnya. Konsekuensi dari kesadaran subjektifnya adalah tindakan subjektivitas memahami Islam secara subjektif dan golongan. Sedangkan, Islam sebagai ilmu bertumpu pada Islam sebagai kesadaran kolektif dan sistem pengetahuan yang objektif. Dari dua konsepsi ini dibangun konstruksi disiplin keilmuan yang baru yakni sosiologi Islam. Sosiologi Islam tidak hanya mengupas Islam sebagai agama. Tapi, Islam adalah konsep keilmuan yang menganalisis dan memahami Islam itu sendiri dan relasinya terhadap agama lain.

Kebutuhan sosiologi Islam adalah menganalisis konteks kemasyarakatan dan pola relasi keagamaan dibutuhkan untuk memetakan persoalan yang dihadapi umat itu sendiri. Titik kelemahan dari teori ISP dari Kuntowijoyo mengesampingkan aspek struktur sebagai aspek pembentukan tindakan sosial dan terjebak pada pengarusutamaan struktur transendental dalam memahami masyarakat. Kuntowijoyo juga terjebak di ranah idealitas atau masyarakat utopis yakni masyarakat tanpa penyimpangan dan bertumpu pada ajaran dan dogma agama sebagai alat kontrol dari keilmuan dan laku masyarakat. Pemahaman Keagamaan dan keilmuan tidak selamanya berbanding lurus dengan sebuah tindakan sosial ataupun laku sosial. Dimensi penyimpangan tersebut menjadi objek kajian dari sosiologi Islam sebagai bentuk dari fenomena kemasyarakatan dan juga pola relasinya terhadap non Islam. Islam tidak bisa dimungkiri sebagai kelompok masyarakat yang tidak tunggal dalam sistem sosial di Indonesia.

Dalam perspektif sosiologi Islam dimensi pola relasi sosial dalam fenomena keberagamaan Islam dapat dilihat dalam dua hal yakni Islam dengan Islam, Islam dengan non Islam, Islam dan lokalitas. Pola hubungan dibentuk berdasarkan hubungan struktur yang statik dan dinamis dari ikatan keagamaan. Sifat kedua hal dalam hubungan ini berdasarkan dari garis pemikiran Aguste Comte sebagai bapak sosiologi. Perbedaan kedua dimensi kemasyarakatan tersebut menjadi penekanan pola hubungan keagamaan. Pola hubungan tersebut dapat dilihat dalam tabel 1.1 berikut 
Tabel 1.1 Pola Hubungan dalam Keagamaan

\begin{tabular}{|l|l|}
\hline Keagamaan dalam Struktur Statik & \multicolumn{1}{|c|}{$\begin{array}{c}\text { Keagamaan dalam Struktur } \\
\text { dinamik }\end{array}$} \\
\hline Status dan Peran & Intensitas relasi antar agama \\
\hline $\begin{array}{l}\text { Model hubungan patron - klien, } \\
\text { kasta, dan Jamaah - ustad, ulama - } \\
\text { Santri, nabi dan rasul- umat, Allah } \\
\text { - Hamba }\end{array}$ & $\begin{array}{l}\text { Pola struktur dalam rentan waktu } \\
\text { tertentu }\end{array}$ \\
\hline Skematik & Dinamik \\
\hline Dapat dikuantifikasi & Deskriptif dapat di kuantifikasi \\
\hline Isu relasi & Adaptasi dan akomodasi \\
\hline $\begin{array}{l}\text { Dogma, pedoman hidup dan } \\
\text { struktur transendental }\end{array}$ & Ajaran dan realitas sosial \\
\hline
\end{tabular}

Aspek sosial yang harus terserap dalam analisis sosiologi Islam dalam pola hubungan keagamaan adalah analisis rasionalisasi instrumental Weberian yang tidak terdapat dalam pemikiran Kuntowijoyo. Weber (2009) memandang bahwa pola hubungan masyarakat didorong pola hubungan kekuasaan dengan pertimbangan kalkulasi rasional [untung dan rugi]. Pola hubungan ini turut menjadi bagian dari interaksi hubungan sosial kemasyarakatan dalam basis keagamaan. Penyerapan pemikiran Weberian ke dalam sosiologi Islam bukanlah hal yang oportunis dalam konteks kemasyarakatan- saat ini. Salvatore (2016) memandang rasionalisasi instrumental kekuasaan harus dilakukan perlawanan [encounter]. Model encounter dilakukan melalui encounter elite budaya dan ilmuwan. Elite budaya dan ilmuwan bertanggung jawab dalam memproduksi pengetahuan dan kategori sosial berdasarkan nilainilai strukturalisme tran- sendental Kuntowijoyo dan rasionalitas transendental tanpa melepaskan pemikiran ilmuwan barat. Rasionalitas transendental tidak hanya memandang bahwa kewahyuan bersifat spesifik, empirik, demistifikasi. Tapi, juga sebagai bentuk kesadaran, perekat, instrumen interaksi sosial.

Bahaya dari hasil produksi pengetahuan dan kategori sosial elite budaya dan ilmuwan adalah 
determinasi elite kekuasaan. Mereka telah melegitimasi diri dan memperoleh senjata legitimasi bersyarat dari penguasa (Salvatore 2016). Legitimasi bersyarat tersebut menjadi alat kekuasaan bekerja. Kekuasaan bekerja dapat dilihat dari konstruksi pengetahuan Peter L Berger.

Teori konstruksi sosial Berger dan Luckmann (1991), hubungan dialektis antar manusia dan masyarakat adalah yakni eksternalisasi, objektivasi, dan internalisasi. Eksternalisasi adalah pembentukan- dunia yang objektif melalui repetisi atau tindakan manusia yang berulang -ulang. Repetisi tindakan manusia menyebabkan pembentukan pola, aturan, peran yang dilakukan manusia. Pembentukan repetisi berangkat dari ajaran dan dogma yang terbentuk dalam sebuah kelompok sosial. Relevansi agama dalam sebuah tindakan repetitif bersumber dari kewahyuan menjadi alat analisis sosiologi Islam. Melewati tahap ini adalah proses institusionaliasi tindakan sebagai proses objektivasi di mana institusi telah menjadi realitas objektif. proses Objektivasi merupakan bagian dari proses legitimasi dan pembenaran atas tindakan sosial yang berulang pada manusia. Pada level objektivikasi, negara sebagai alat kekuasaan bekerja melegitimasi pengetahuan maupun alat kejahatan sosial. Sedangkan, Tahap institusionalisasi menjadi mediator proses internalisasi atau penyerapan nilai-nilai dari masyarakat yang terintitusi dalam masyarakat yang sudah terobjektivasi (Poloma 1992; Riyanto 2009; Samuel 2012; Friedman 2016).

Dalam kajian sosiologi Islam penting mengadopsi dan memformulasikan kembali pemikir- an Berger dalam menganalisis- konteks masyarakat Islam dengan memadukan pemikir- an Kuntowijoyo. Berger dan Kuntowijoyo (2007) meyakini kehidupan kemasyarakatan sebagai semesta simbolis dan agama memiliki hukumnya masing masing. Perbedaan kedua pemikir tersebut adalah Kuntowijoyo rasionalitas dan realitas keagamaan adalah bagian integral dari kesadaran penganutnya antara pemahaman agama dan ritual memiliki konsekuensi sosial yang ideal sesuai visi kenabian [profetik]. Kuntowijoyo menghindari proses sekularisasi dalam pengilmuan Islam. Sementara, Berger membedakan kesadaran pada level individual dan level kemasyarakatan dalam penyerapan nilai - nilai 
sekularisasi. Di level individu sekularisasi berlangsung di tingkat kesadaran pemisahan logika dunia dan logika agama sedangkan di level masyarakat, sekularisasi berlangsung melalui penyingkiran urusan agama dalam urusan legalformal yang harus diurus dengan pihak netral (Riyanto 2009).

Pemikiran Berger mengenai Fenomena keberagamaan mengutamakan rasionalisasi atau formulasi ajaran keagamaan untuk menyesuaikan kondisi sosialnya (Riyanto 2009). Prinsip ini diadopsi bagi agama - agama yang minoritas berupaya melakukan adaptasi terhadap agama dominan di sekitarnya. Sementara, Agama mayoritas bertindak akomodatif terhadap minoritas. Dalam disiplin kajian sosiologi Islam membangun model evaluatif realitas keberagamaan dan meruntuhkan ajaran dogma agama sebagai basis radikalisme dan pemikiran fundamentalisme. Dalam perumusan kerangka pemikiran sosiologi Islam sebagai sistem kemasyarakatan sebagai berikut :

\section{Bagan 1.0 Model Evaluasi Realitas sosiologi Islam}

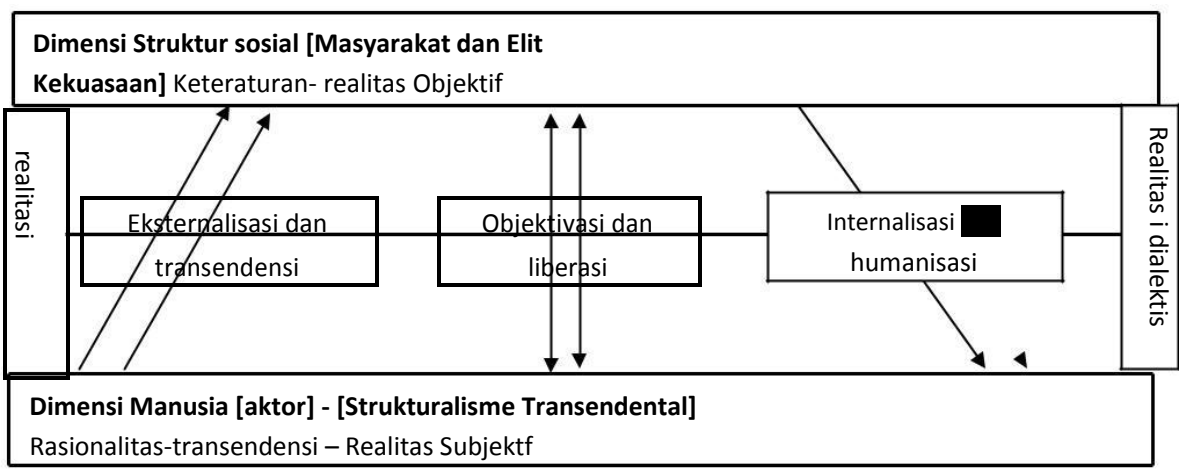

Sumber : Bagan diformulasikan dari Riyanto (2009)

Dalam bagan 1.0 menunjukkan dua dimensi kemasyarakatan dimensi struktur sosial yakni masyarakat dan kekuasaan sebagai model keteraturan dan realitas objektif. Struktur sosial dalam dimensi ini bisa dimaknai sebagai relasi sosial, wacana, aturan, tindakan, stratifikasi, sumber daya, kekuasaan, rekayasa sosial, dan keterlekatan sosial [etnik dan jenis kelamin] (Kingseng 2017).

Dimensi manusia [aktor] sebagai realitas subjektif yang menjadi 
bagian dari kualitas aktor dalam membangun relasi sosial. Realitas subjektif tidak lepas kesadaran aktor atau struktur kognitif yang dimilik aktor dalam memahami dunia di sekitarnya. Realitas sub- jektif ini terbentuk berdasarkan pada realitas objektif atau dalam dimensi agama realitas kewahyuan. Realitas kewahyuan adalah bagian dimensi rasionalitas transendensi. Rasionalitas transendensi adalah kualitas hubungan yang dibangun berdasarkan nilai - nilai kewahyuan. Kewahyuan adalah realitas subjektif yang didapatkan dari pengalaman mistik atau pengalaman rohani sang aktor. Nilai - nilai kewahyuan melekat dalam suatu agama atau ajaran tertentu.

Hubungan antara dimensi struktur dan dimensi manusia [aktor] adalah realitas dialektis dalam sistem kemasyarakatan atau realitas sosiologis yang terbentuk berdasarkan hubungan keagamaan melalui mekanisme eksternalisasi [repetisi nilai] atau penanaman nilai dari kualitas aktor. Dalam proses eksternalisasi, Sosiologi menjadi alat evaluasi dalam memahami agama sebagai ajaran, ilmu, dan dogma. Objektivasi adalah institusionalisasi nilai atau pelegitimasian nilai baik sebagai realitas subjektif maupun realitas objektif. Objektivasi menjadi bagian paling krusial dalam melihat hubungan antara dimensi struktur dan dimensi aktor dalam perebutan atau rekonsiliasi nilai - nilai dalam memandang dunia. Pengaruh dominasi dari dimensi ini bisa dilihat dari kualitas pengaruh dari satu antara dimensi aktor atau struktur atau realitas subjektif atau objektif dalam proses liberasi atau emansipasi. Sementara, internalisasi adalah penyerapan nilai dari realitas objektif dan penegakan nilai - nilai kebajikan [nilai keagamaan] dalam melangsungkan penghidupan aktor.

Dalam kajian sosiologi Islam dalam makalah ini yakni : pertama, analisis pola hubungan keberagamaan Islam dengan dengan non Islam. kedua, evaluasi keberagamaan Islam sebagai dimensi dogma, ajaran, dan sistem kemasyarakatan. Pengkajian sosiologi Islam dalam dua aspek upaya refleksi atas realitas kemayoritasan umat Islam sebagai sistem nilai dan sistem kemasyarakatan di Indonesia. Dalam pengkajian sosiologi Islam menurut Salvatore (2016) adalah upaya pemadatan pengkajian realitas sosial bahwa Islam adalah kelompok sosial yang memiliki sistem nilai dan sistem kemasyarakatan sendiri. Meskipun, sosiologi Islam sebagai hibridisasi keilmuan etik sosiologis 
harus dijaga 11.

\section{FENOMENA}

\section{KEBERAGAMAAN ISLAM}

Penggunaan istilah keberagamaan umat Islam adalah frase yang janggal dalam penggunaannya. Penggunaan keberagamaan umat Islam merujuk pada kelompok sosial yang memiliki sistem budaya kemasyarakatan [societal culture]. Budaya kemasyarakatan adalah bangunan kelompok sosial yang memiliki perangkat keyakinan, historis, tata nilai, dan institusi. Alternatif lain pengganti frase keberagamaan umat Islam adalah penganut Islam. Sementara, penggunaan frase penganut Islam tidak mewakili Islam sebagai sistem kemasyarakatan. Tapi, kelompok sosial yang meyakini Islam sebagai penganut doktrin agama Islam.

11 Etik yang harus dipegang bagi sosiolog menurut Peter L Berger. 1985. Humanisme Sosiologi. Sebagai bentuk kesadaran sosiologis adalah : pertama, motif pembongkaran/penelanjangan [debungking], motif ketidakhormatan [motif penghargaan terhadap berbagai profesi dalam masyarakat], Ketiga, motif penisbian [peluruhan nilai - nilai dan identitas yang melekat dalam diri aktor dalam mengamati objek sosial; Keempat, motif kosmopolitan [keterbukaan terhadap cakrawala baru dan pemaknaan baru terhadap lingkungan sekitar.
Dalam fenomena keberagamaan sebagai perangkat pemikiran, keyakinan, historis, tata nilai, dan institusi. Maka, realitas sosial keberagamaan Islam Indonesia memiliki realitas historis yang panjang dalam pembentukan kebangsaan Indonesia. Fakta historis bisa ditinjau dari perangkat pemikiran sebagai pengetahuan dan ideologi, keyakinan sebagai doktrin, ajaran Sebagai agama, sistem nilai sebagai wujud fakta sosial, dan institusi sebagai wujud dari pelembagaan. Fakta historis tidak bisa dilepaskan dari konteks masyarakat baik secara faktual maupun secara simbolis. Secara faktual Islam diperhadapkan berbagai macam konflik dan ketegangan antara pemeluk agama yang lain. Selain itu, dalam internal Islam sendiri memiliki persinggungan antara golongan mengenai klaim kebenaran. Sementara, secara simbolis fenomena keberagamaan diperhadapkan perangkat kelembagaan, simbol, nila terhadap sistem kehidupan yang diperjuangkan. Problem - problem keberagamaan umat Islam sebagai fakta historis dalam mewarnai perjalanan kebangsaan Indonesia sebagai berikut : 
Tabel 1.3. Fenomena Keberagamaan Umat Islam di Indonesia

\begin{tabular}{|c|c|c|c|c|c|}
\hline \multirow{2}{*}{$\begin{array}{l}\text { Periode } \\
\text { waktu }\end{array}$} & \multirow{2}{*}{ Peristiwa } & \multirow{2}{*}{ Waktu } & \multicolumn{3}{|l|}{ Proses Simbolis } \\
\hline & & & Lembaga & Simbol & Norma \\
\hline \multirow{4}{*}{$\begin{array}{l}\text { Orde } \\
\text { Lama }\end{array}$} & Piagam Jakarta & $\begin{array}{l}\text { 22 Juni } \\
1945 \\
\end{array}$ & Negara & Realisme & $\begin{array}{l}\text { Dasar hukum, } \\
\text { demistifikasi }\end{array}$ \\
\hline & & 1949 - & Militer, Negara & & \\
\hline & DI/TII & 1965 & Islam & mistik & Dasar Hukum \\
\hline & $\begin{array}{l}\text { Pembubaran } \\
\text { Masyumi dan } \\
\text { PSI }\end{array}$ & $\begin{array}{l}17 \\
\text { Agustus } \\
1960 \\
\end{array}$ & $\begin{array}{l}\text { Partai, } \\
\text { profesional, } \\
\text { Kontra revolusi }\end{array}$ & $\begin{array}{l}\text { Pseudo } \\
\text { realisme }\end{array}$ & $\begin{array}{l}\text { Nasionalisme, } \\
\text { Modifikasi, } \\
\text { perilaku }\end{array}$ \\
\hline \multirow{4}{*}{ Orde Baru } & $\begin{array}{l}\text { Perang Suci } \\
\text { [PKI VS } \\
\text { Muhammadiya } \\
\text { dan NU } \\
\end{array}$ & $\begin{array}{l}1965 \\
-1966\end{array}$ & $\begin{array}{l}\text { Partai, } \\
\text { Profesionalisme, } \\
\text { Organisasi } \\
\text { Masyarakat }\end{array}$ & $\begin{array}{l}\text { Pseudo } \\
\text { Mistik }\end{array}$ & $\begin{array}{l}\text { mistifikasi, } \\
\text { Ajaran, dan } \\
\text { Dogma }\end{array}$ \\
\hline & $\begin{array}{l}\text { Penerapan } \\
\text { Asas Tunggal }\end{array}$ & $\begin{array}{l}1985 \\
-1998\end{array}$ & Negara, Perintah & $\begin{array}{l}\text { Psedo } \\
\text { Realisme }\end{array}$ & $\begin{array}{l}\text { Nasionalisme, } \\
\text { sekularisme, } \\
\text { Otoritarian }\end{array}$ \\
\hline & Tanjung Priok & 1984 & $\begin{array}{l}\text { Negara, } \\
\text { birokrasi } \\
\text { Asas tunggal }\end{array}$ & $\begin{array}{l}\text { Pseudo } \\
\text { realisme }\end{array}$ & $\begin{array}{l}\text { Nasionalisme, } \\
\text { Sekularisme, } \\
\text { Otoritarian }\end{array}$ \\
\hline & Talangsari & 1989 & $\begin{array}{l}\text { Negara, } \\
\text { birokrasi } \\
\text { Asas tunggal }\end{array}$ & $\begin{array}{l}\text { Pseudo } \\
\text { realisme }\end{array}$ & $\begin{array}{l}\text { Nasionalisme, } \\
\text { Sekularisme, } \\
\text { Otoritarian }\end{array}$ \\
\hline \multirow{5}{*}{$\begin{array}{l}\text { Orde } \\
\text { Reformasi }\end{array}$} & $\begin{array}{l}\text { Konflik } \\
\text { Ambon dan } \\
\text { Sambas } \\
\end{array}$ & 1999 & Etnisitas & $\begin{array}{l}\text { Pseudo } \\
\text { mistik }\end{array}$ & $\begin{array}{l}\text { Kontra nilai, } \\
\text { Kesadaran } \\
\text { ektnisitas }\end{array}$ \\
\hline & Konflik Poso & $\begin{array}{l}1998- \\
2001\end{array}$ & Agama & \begin{tabular}{|l} 
Pseudo \\
Mistik \\
\end{tabular} & $\begin{array}{l}\text { Eksklusivitas, } \\
\text { Klaim otoritas }\end{array}$ \\
\hline & $\begin{array}{l}\text { Gereja Yasmin } \\
\text { Bogor }\end{array}$ & 2010 & Agama & $\begin{array}{l}\text { Pseudo } \\
\text { mistik } \\
\end{array}$ & $\begin{array}{l}\text { Eksklusivitas, } \\
\text { Klaim otoritas }\end{array}$ \\
\hline & $\begin{array}{l}\text { Demonstrasi } \\
\text { Penistaan } \\
\text { agama } \\
\end{array}$ & $\begin{array}{l}2017 \\
-2018\end{array}$ & $\begin{array}{l}\text { Organisasi } \\
\text { Masyarakat, } \\
\text { Massa } \\
\end{array}$ & $\begin{array}{l}\text { Pseudo } \\
\text { mistik }\end{array}$ & $\begin{array}{l}\text { Eksklusivitas, } \\
\text { Klaim otoritas }\end{array}$ \\
\hline & $\begin{array}{l}\text { Pembubaran } \\
\text { HTI }\end{array}$ & 2018 & $\begin{array}{l}\text { Partai, birokrasi } \\
\text { Kontra Kontra } \\
\text { Pancasila }\end{array}$ & $\begin{array}{l}\text { Pseudo } \\
\text { mistik }\end{array}$ & $\begin{array}{l}\text { Nasionalisme, } \\
\text { Eksklusivitas, }\end{array}$ \\
\hline
\end{tabular}

Sumber : Kuntowijoyo (2006a), Ricklefs (2008) Maarif (2009), Akmalia (2016) Suwirta (2018) 
Berdasarkan peristiwa Keberagamaan Umat Islam di Indonesia dalam tiga periode memiliki ciri masing - masing sebagai peristiwa simbolik dan historis. Di masa Orde Baru relasi keagamaan umat Islam lebih dominan bersinggungan dengan negara dalam perumusan dasar hukum negara mulai dari piagam Jakarta, Pemberontakan Darul Islam/Tentara Islam Indonesia [DI/TII], dan pembubaran orga- nisasi kemasyarakatan Partai Serikat Islam [PSI] dan Partai Majelis Syuro Muslimin Indonesia [Masyumi]. Ketiga peristiwa sejarah menunjukkan ketegangan simbolis antara pendukung hukum sekuler dan hukum agama. Pendukung hukum sekuler bersikukuh meng- hilangkan kalimat Ketuhanan, dengan kewajiban menjalankan syariat Islam bagi pemeluk - pemeluknya. Konsekuensi kalimat ini di Piagam Jakarta sebagai upaya Demistifikasi Islam sebagai hukum sekuler yang mengatur keberagaman penduduk Indonesia. Sementara, Para penggagas hukum sekuler pada terjebak Piagam Jakarta cara berpikir realisme.12 Bias dari penghilangan

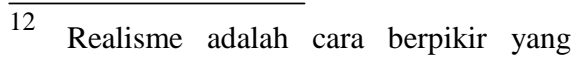
bertumpu pada karakter objektivitas dan common sense [pengetahuan umum] dari pengalaman indrawi. Dalam politik realisme, negara menjadi tujuh kata dalam Piagam Jakarta adalah pemberontakan DI/TII yang berlangsung di beberapa Daerah 1946 - 1965, Jawa Barat, Aceh, Kalimantan, dan Sulawesi Selatan.

Pada periode Orde Baru, bentuk relasi umat Islam dan negara adalah intimidasi. Negara dikontrol oleh aparatus negara yakni elite, birokrasi, dan militer. Norma yang mendominasi mereka adalah nasionalisme, sekularisme, dan otoritarianisme. Sekularisme yakni pemisahan hukum agama dan politik dalam menyelenggarakan pemerintahan negara. Wujud penyelenggaraan negara yang mengedepankan- nasionalisme dan sekularisme berwujud otoritarianisme dengan penerapan asas tunggal. Para penyelenggara negara terjebak pseudo realisme ${ }_{13}$ yakni negara adalah kekuatan tunggal dalam mengendalikan keamanan dan ketertiban dalam menjalankan pembangunan.

Di masa Orde Reformasi pola hubungan ketegangan dan intimidasi

otoritas penuh mengendalikan atau mengontrol kehidupan warganya. Dalam Upcher, James. 2009. Christian Reus-Smit and Duncan Snidal (eds). The Oxford Handbook of International Relations.

Pseudo realisme adalah cara berpikir dan bersikap pragmatis dalam idealitas moral dan tatanan sosial. 
negara terhadap berangsur - angsur menghilang. Tapi, konflik antara pemeluk agama lain makin mencuat dengan munculnya ber- bagai isu sara antara berbagai pemeluk agama. Sikap eksklusivitas muncul di beberapa agama dengan menguatnya sentimen etnisitas [kesadaran etnisitas] untuk me- nyingkirkandan memarjinalkan kelompok tertentu. Ketegangan yang muncul antara agama disebab- kan hubungan yang klise antara penganut agama dominan dengan penganut minoritas terkait klaim otoritas kebenaran. Dominasi mayoritas tergambar pada peristiwa penutupan gereja Yasmin Bogor dan beberapa kasus serupa pernah terjadi. Munculnya sikap eksklusivitas dan klaim otoritas kebenaran terbentuk karena cara pandang yang diselimuti pseudo mistik.14

Pola hubungan keberagamaan umat Islam dari tiga fase historis dan simbolis dapat disimpulkan menjadi empat hal yakni ketegangan perumusan dasar negara, ketegangan ideologis, kediktatoran negara, dominasi mayoritas. Pola hubungan

14 Pseodu mistik adalah cara berpikir dan bersikap mengagunkan otoritas kewahyuan dan menanggalkan sumber-sumber kebenaran selain dari golongannya. Satu ciri dari Pseodu mistik adalah berpikir dogmatis. tersebut merupakan bias dari objektivitas dogma agama yang terlihat dari sikap moral yang ditunjukkan yakni eksklusivitas, klaim otoritas kebenaran, perumusan hukum Tuhan, dan modifikasi perilaku berdasarkan ajaran keagamaan. Bias objektivitas dogma agama sebagai wujud dari kesadaran palsu yang dimiliki oleh para penganutnya. Bentuk kesadaran palsu dalam keseharian menurut Mennheim (1991) adalah kecurigaan yang bercokol dalam jiwa manusia. Kecurigaan tersebut menurut Mennheim (1991) berasal dari sikap religius.

\section{BIAS OBJEKTIVITAS,} AJARAN, DAN DOGMA ISLAM

Karl Mannheim (1991) mempertanyakan- kembali rumusan masalah objektivitas dalam kaidah ilmiah sebagai kaidah kebenaran. Kaidah ilmiah yang selama ini kita akui sebagai klaim metodologis dan pembuktian ilmiah. Tiada lain adalah tradisi keagamaan yang di dalamnya ada metode pembuktian dan metode yang memperlihatkan kesesatan pandangan yang berlainan. Bahkan, bisa dikuantifikasi. Pan- dangan ini menjadi titik tolak lahirnya sebuah ajaran yang terikat dengan dogma. Ukuran objektivitas dalam pengetahuan adalah ukuran 
dogmatis dalam agama.

Pembuktian ilmiah yang dilakukan para ilmu- wan harus diterima sebagai kebenaran. Begitupun, dogma agama. Prinsip dasar ini menjadi titik nadir sebuah ajaran keagamaan dalam mengaktualkan nilai-nilai dogmatis di lingkungan masyarakat yang beragam.

Objektivitas dogma agama sebagai nilai kebenaran, diyakini tanpa gugatan dan dilakukan tanpa prasangka. Ikatan kuat ini dibangun di atas doktrin keagamaan yang kuat. Kebenaran dalam agama tidak perlu dipertanyakan lagi dan digalih berdasarkan metode ilmiah. Pandangan ini adalah Bias Objektivitas dogma yang harus dikesampingkan. Sebab, meyakini Objektivitas dogma sebagai kebenaran sama halnya melahirkan eksklusivitas dan marginaliasi terhadap kebenaran yang lain. Ruang dialog pengetahuan maupun interaksi sosial terhambat. Bias objektivitas dogma sangat terlihat dalam pola hubungan keberagamaan umat Islam di Indonesia dari masa ke masa.

Bias objektivitas dogma agama dalam pandangan Kuntowijoyo (2006) yakni involutif dan ekspansif. Bias involusi merupakan wujud pendangkalan keilmuan dan ajaran keagamaan. Bias involusi ini adalah meyakini kebenaran para pendahulu sebagai kebenaran yang objektif dan standar pengetahuan yang baru. Dalam pandangan Geerzt (1983) Involusi adalah, kemandekan dan kemacetan.15 Sedangkan, bias ekspansif dalam pandangan Kuntowijoyo (2006) meyakini bukan agama sebagai agama. Bias ekspansif memberikan pendikotomian masa lalu antara kaum modernis dan tradisionalis. Bias ekspansif menyebabkan sikap ekslusi [penyingkiran] terhadap golongan lain yang bukan sebagai golongannya.

Bahaya laten dari bias objektivitas dogma adalah konfliktual ketika berhadapan dengan sikap ekslusivitas yang lain. Periode ini berlangsung di awal - awal periode reformasi sebagai imbas konflik laten di masa Orde Baru. Di masa Orde Baru, agama lokalitas tidak memiliki tempat sebagai bentuk kepercayaan dan dilegitimasi oleh undang - undang. Di balik itu, ada pertarungan pengaruh untuk merebut simpatisan lokalitas menerima agama yang diakui negara

$\overline{15}$ Istilah involusi digunakan Clifford Gertz untuk menggambarkan suatu kemacetan dan kemandekan pertanian di Jawa. Istilah Involusi merujuk pada istilah perubahan sosial yang menunjukkan gerak yang tidak berarti atau pergerakan yang lamban. 
[Islam, Hindu, Budha, Kristen [Protestan dan Katolik]. Validasi sejarah membuktikan bahwa terdapat bahaya bias objektivitas dogma antar agama.

\section{PENUTUP}

Sosiologi Islam adalah disiplin keilmuan yang membekukan kajiannya di ranah kelompok masyarakat Islam. Sosiologi Islam berupaya memotret kelompok masyarakat Islam yang memiliki sistem budaya kemasyarakatan yang terbangun atas sistem nilai, keyakinan, historis, dan moralitas sendiri. Dalam lingkup kajian sosiologi Islam dalam tulisan ini merefleksikan sikap keberagamaan umat Islam di Indonesia yang menunjukkan pola hubungan keberagamaan yang kompleks bukan hanya fakta demografi sebagai masyarakat mayoritas di Indonesia. Selain itu, pola relasi yang terbentuk adalah determinasi negara terhadap umat, ketegangan konfliktual antara pemeluk agama Islam dengan yang lain. Pola hubungan tersebut disebabkan karena keyakinan terhadap bias objektivitas dogma agama sebagai bagian dari kebenaran. Bias dogma agama menyebabkan sikap eksklusivitas dan klaim otoritas kebenaran satu sama lain. Wujud kesadaran sosiologi harus dibangun dengan mengakui, yang lain [pihak lain] sebagai kekuatan sosial.

Dalam ruang yang terbatas dalam makalah ini, kajian sosiologi Islam perlu diperluas kembali. Sosiologi Islam harus mencakup sebagai alat analisis evaluasi kemasyarakatan dan bukan hanya keilmuan teoritis maupun diskripsi sosiologis. Pengkajian sosiologi Islam harus mencapai tepi akhir dari keilmuan dalam melihat budaya kemasyarakatan umat Islam. Pengembangan lain dari sosiologi Islam adalah penggabungan berbagai disiplin keilmuan maupun berbagai paradigma dalam sosiologi, misalnya paradigma konstruksi pengetahuan, fakta sosial, definisi sosial, dan paradigma yang lain berdasarkan metateori yang dibangun para sosiologi barat maupun ilmuwan islam.

\section{Daftar Pustaka}

Abidin, Zainal. 2016. Paradigma Islam dalam Pembangunan Ilmu Integralistik : Membaca Pemikiran Kuntowijoyo. Banjarmasin : IAIN Antasari Press.

Abidin, Zainal, Agus Ahmad Safei, and Maman Abdul Djaliel. 2003. Sosiosophologi: sosiologi 
Islam berbasis hikmah.

Bandung : Pustaka Setia.

Akmaliah, Wahyudi. 2016.

Indonesian Muslim killings: revisiting the forgotten Talang Sari tragedy (1989) and its impact in post authoritarian regime. Indonesian Journal of Islam and Muslim Societies. 6.(1) : 1-34.

Alqadrie, Syarif. 2014. Konflik

Etnis di Ambon dan Sambas: Suatu Tijauan Sosiologis. Antropologi Indonesia.

Berger, Peter L. 1985. Humanisme

Sosiologi. Jakarta : Inti Sarana Aksara.

Berger, Peter L, Frans M. Parera, and Thomas Luckman.1990. Tafsir sosial atas kenyataan: Risalah tentang sosiologi pengetahuan. Yogyakarta : LP3ES.

Friedman, Asia M. 2016. Perceptual Construction: Rereading The Social Construction of Reality Through the Sociology of the Senses. Cultural Sociology 10(1):77-92.

Geertz, Clifford. 1976. Involusi

Pertanian: Proses Perubahan Ekologi Di Indonesia, Diterjemahkan Oleh S. Supomo. Jakarta : Bhratara.
Jurdi, Syarifuddin. 2010. Sosiologi Islam \& Masyarakat Modern. Yogyakarta : Prenada Media. Kuntowijoyo. 2006. Budaya dan masyarakat. Yogyakarta : Tiara Wacana.

Kinseng, Rilus A. 2017. Structugency: A Theory of Action. Sodality: Jurnal Sosiologi Pedesaan 5.(2).

Kuntowijoyo. 2007. Islam Sebagai Ilmu: Epistemologi, Metodologi, dan Etika. Yogyakarta : Tiara Wacana.

Kusumadewi, Lucia Ratih. 2012. Relasi Sosial Antar Kelompok Agama di Indonesia : Integrasi atau disintegrasi. Di dalam Wirutomo, Paulus. Sistem Sosial Indonesia. Depok : Lab sosio-UI.

Maarif, Ahmad Syafii. 2009. Islam dalam bingkai keindonesiaan dan kemanusiaan: sebuah refleksi sejarah. Jakarta : Mizan.

Mannheim, Karl. 1991. Ideologi dan Utopia: Menyingkap Kaitan Pikiran dan Politik. Yogyakarta : Kanisius.

Muttaqin, Husnul. 2006. Menuju Sosiologi Profetik. Jurnal Sosiologi Reflektif. 10(1).

Poloma, Margaret M. 1987. Sosiologi kontemporer. Jakarta : Rajawali Pers. 
Riyanto, Geger. 2009. Peter L. Berger: perspektif metateori pemikiran. Yogyakarta : LP3ES.

Ricklefs, Merle Calvin. 2008. A History of Modern Indonesia since c. 1200. Macmillan International Higher Education.

Salvatore, Armando. 2005. Religion, social practice, and contested hegemonies: reconstructing the public sphere in Muslim majority societies. London [UK]. Springer.

Samuel, Hanneman. 2012. Peter

Berger: Sebuah Pengantar Ringkas. Depok [ID]: Penerbit Kepik.
Suwirta, Andi. 2018. Pers dan Kritik Sosial pada Masa Orde Baru: Kasus Peristiwa Tanjung Priok Tahun 1984 dalam Pandangan Surat Kabar Merdeka dan Kompas di Jakarta. Insancita 2(2) Upcher, James. 2009. Christian Reus-Smit and Duncan Snidal (eds). The Oxford Handbook of International Relations.

Weber, Max. 2009. Sosiologi, terj., Noorkholish, dkk., Yogyakarta: Pustaka Pelajar. 